US Army Corps

of Engineers ${ }_{\circledast}$

Engineer Research and

Development Center

Integrated Climate Assessment for Army Enterprise Planning

\title{
Growing Degree Days Model User's Guide
}

Byron M. Garton

July 2019

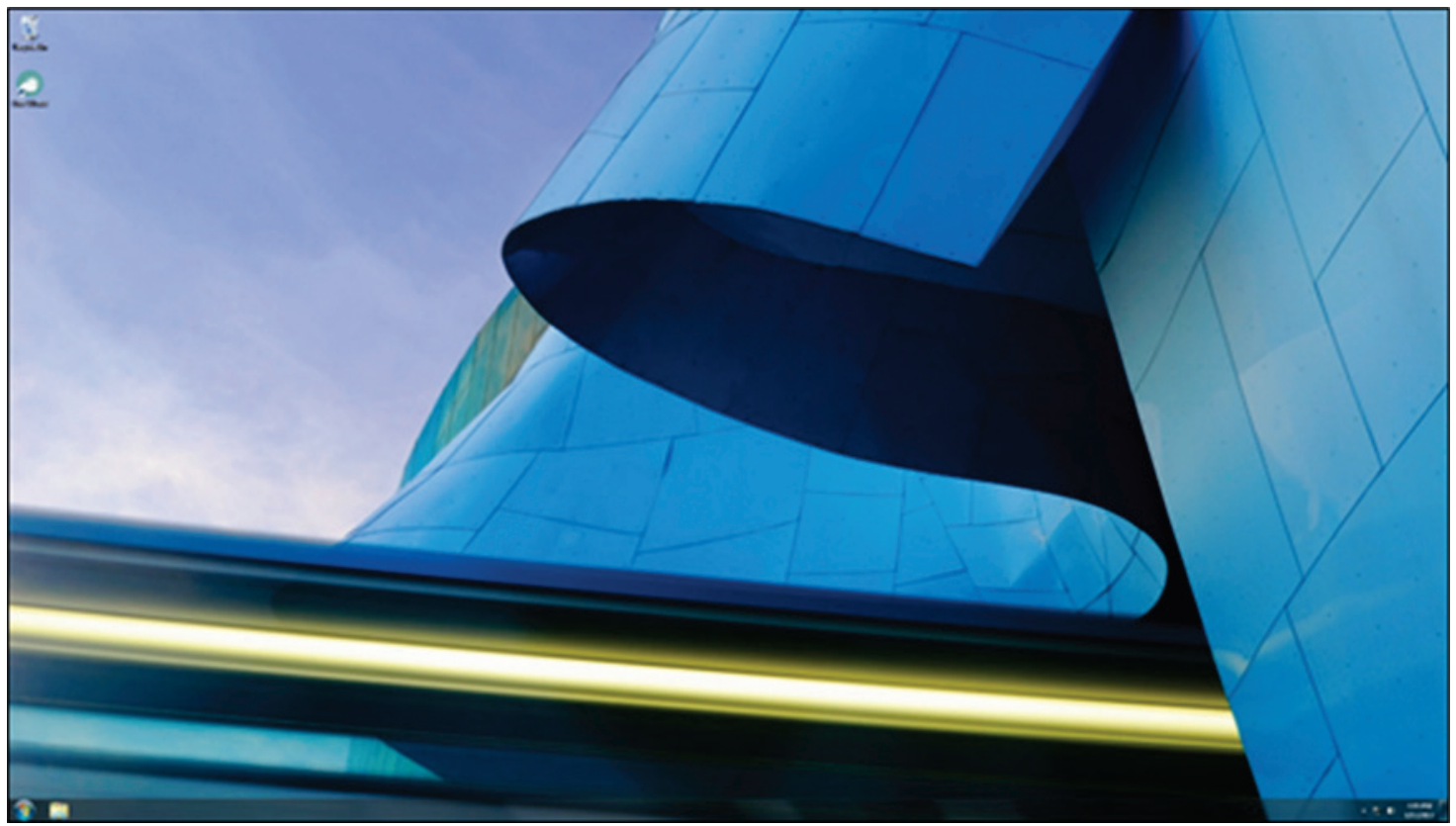


The U.S. Army Engineer Research and Development Center (ERDC) solves the nation's toughest engineering and environmental challenges. ERDC develops innovative solutions in civil and military engineering, geospatial sciences, water resources, and environmental sciences for the Army, the Department of Defense, civilian agencies, and our nation's public good. Find out more at www.erdc.usace.army.mil.

To search for other technical reports published by ERDC, visit the ERDC online library at http://acwc.sdp.sirsi.net/client/default. 


\title{
Growing Degree Days Model User's Guide
}

\author{
Byron M. Garton \\ Information Technology Laboratory \\ U.S. Army Engineer Research and Development Center \\ 3909 Halls Ferry Road \\ Vicksburg, MS 39180-6199
}

Final report

Approved for public release; distribution is unlimited.

Prepared for Headquarters, U.S. Army Corps of Engineers

Washington, DC 20314-1000

Under Project 402188 Integrated Climate Assessment for Army Enterprise Planning 


\section{Abstract}

Maintaining and increasing the capacity to perform maneuver training exercises on Department of Defense (DoD) lands is essential to future force readiness and effectiveness. The risk of reduction of vegetation growth on ranges as a potential result of climate change is one factor affecting the availability of training areas. Assessing the impact of future climate change is an essential part of ensuring future availability of maneuver ranges.

This document describes the process of executing the Growing Degree Days Model, as it exists at the time of this writing, within the common computational environment established under the software integration effort of the Integrated Climate Assessment for Army Enterprise Planning work package.

DISCLAIMER: The contents of this report are not to be used for advertising, publication, or promotional purposes. Citation of trade names does not constitute an official endorsement or approval of the use of such commercial products. All product names and trademarks cited are the property of their respective owners. The findings of this report are not to be construed as an official Department of the Army position unless so designated by other authorized documents. 


\section{Contents}

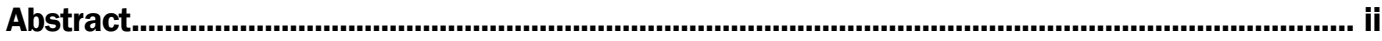

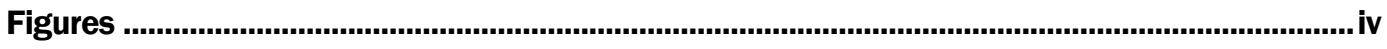

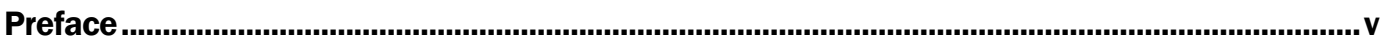

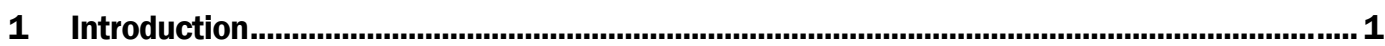

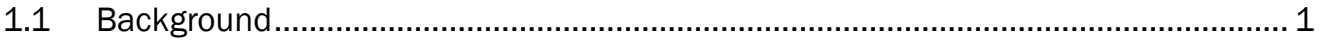

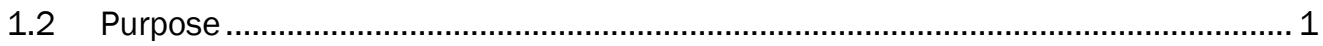

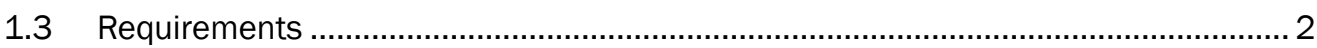

2 Viewing Computed Data ................................................................................................. 3

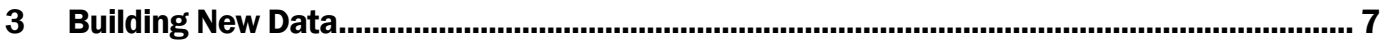

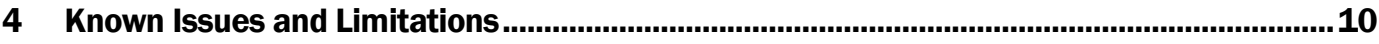

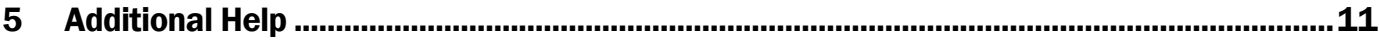

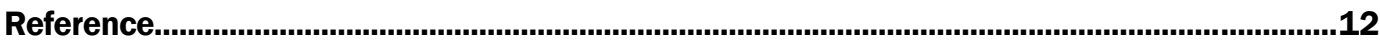

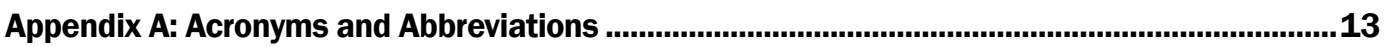

Report Documentation Page 


\section{Figures}

\section{Figures}

Figure 1. Wizard application shortcut. ...................................................................................... 3

Figure 2. Growing Degree Days Model icon................................................................................. 4

Figure 3. Growing Degree Days Model first screen.......................................................................... 4

Figure 4. Growing Degree Days Model second screen.................................................................. 5

Figure 5. Results in the chart viewer window. ........................................................................... 6

Figure 6. Launch Python IDLE from the third model screen within the Wizard................................... 7

Figure 7. Python IDLE development environment. ……………................................................... 8

Figure 8. Data Fixer tool....................................................................................................... 9 


\section{Preface}

This research was conducted for the U.S. Engineer Research and Development Center-Construction Engineering Research Laboratory (ERDC-CERL) under Project 402188, Integrated Climate Assessment for Army Enterprise Planning. The Technical Monitor was Dr. James D. Westervelt of ERDC-CERL.

The work was performed by the Information Technology Laboratory (ITL), Scientific Software Branch (SSB), of the Computational Science and Engineering Division (CSED). At the time of publication, Mr. Timothy W. Dunaway was Chief of the SSB, Dr. Jerrell R. Ballard was Chief of the CSED, and Dr. Robert M. Wallace was the Technical Director. The Deputy Director of ERDC-ITL was Ms. Patti S. Duett, and the Director was Dr. David A. Horner.

COL Ivan P. Beckman was the Commander of ERDC, and Dr. David W. Pittman was the Director. 


\section{Introduction}

\subsection{Background}

The Growing Degree Days Model attempts to predict the number of growing degree days that will occur in the future based on future climate projections for various Department of Defense (DoD) installations. Growing degree days (GDD) is a weather-based indicator related to heat accumulation from air temperature for assessing the suitability for growing plan life in a specific region.

Maintaining and increasing the capacity to perform maneuver training exercises on DoD lands is essential to future force readiness and effectiveness. This requires robust growth, regeneration, and resiliency of vegetation. Assessing the impact of future climate change is an essential part of ensuring future availability of maneuver ranges. The predicted effect of climate change on growing degree days is intended to be utilized in other force stationing analysis applications as a Military Value Analysis (MVA) attribute.

\subsection{Purpose}

This model makes use of a common computational environment and a user assistance application that were implemented as part of the Software Integration effort within the Integrated Climate Assessment for Army Enterprise Planning work package. The virtual environment will be referred to throughout this document as the Virtual Machine or VM, and the user assistance application will be referred to as the Wizard. For more information about the Software Integration effort, the virtual environment, and the user assistance application, refer to the Analytical Model Integration Methods technical report listed in the reference section.

Executing the model is a two-step process that requires using Python IDLE development environment, MS Excel ${ }^{\circledR}$, and a basic text editor such as MS Notepad ${ }^{\circledR}$. Each step for viewing and building data sets is thoroughly documented in the following sections to limit user confusion and ensure accurate results. 


\subsection{Requirements}

Software requirements for the Growing Degree Days Model include the Python IDLE development environment, a basic text editor such as MS Notepad ${ }^{\circledR}$, and MS Excel ${ }^{\circledR}$ version 2013 or higher.

A working knowledge of Microsoft Office products is recommended as well as a basic understanding of editing file paths in a text file and executing Python code within the IDLE environment. 


\section{Viewing Computed Data}

Pre-built dataset viewing is available to end users by accessing the model from within the Wizard application. The Wizard is accessible from the Integrated Climate Assessment for Army Enterprise Planning VM by clicking the shortcut located on the desktop (Figures 1-3).

Figure 1. Wizard application shortcut.

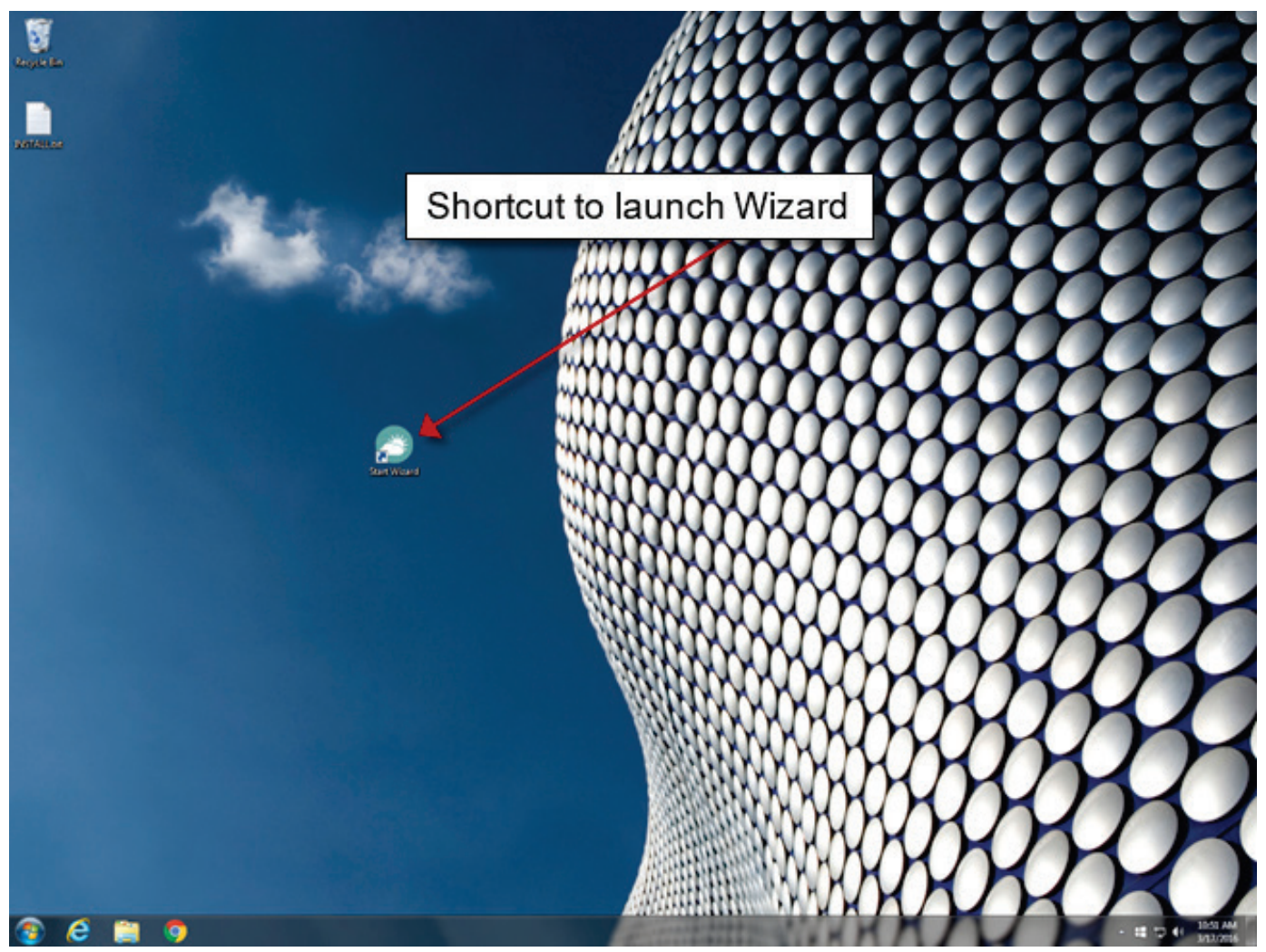


Figure 2. Growing Degree Days Model icon.

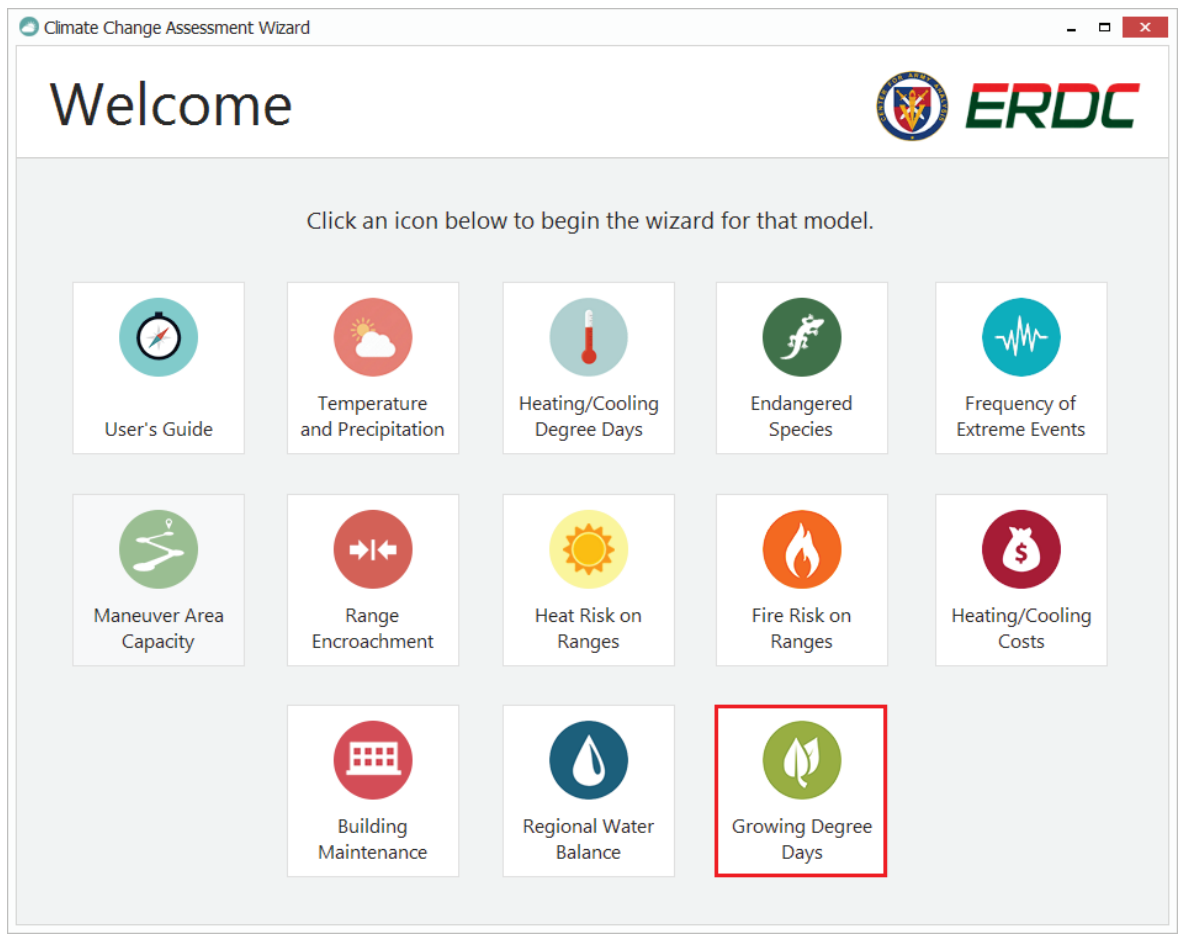

Figure 3. Growing Degree Days Model first screen.

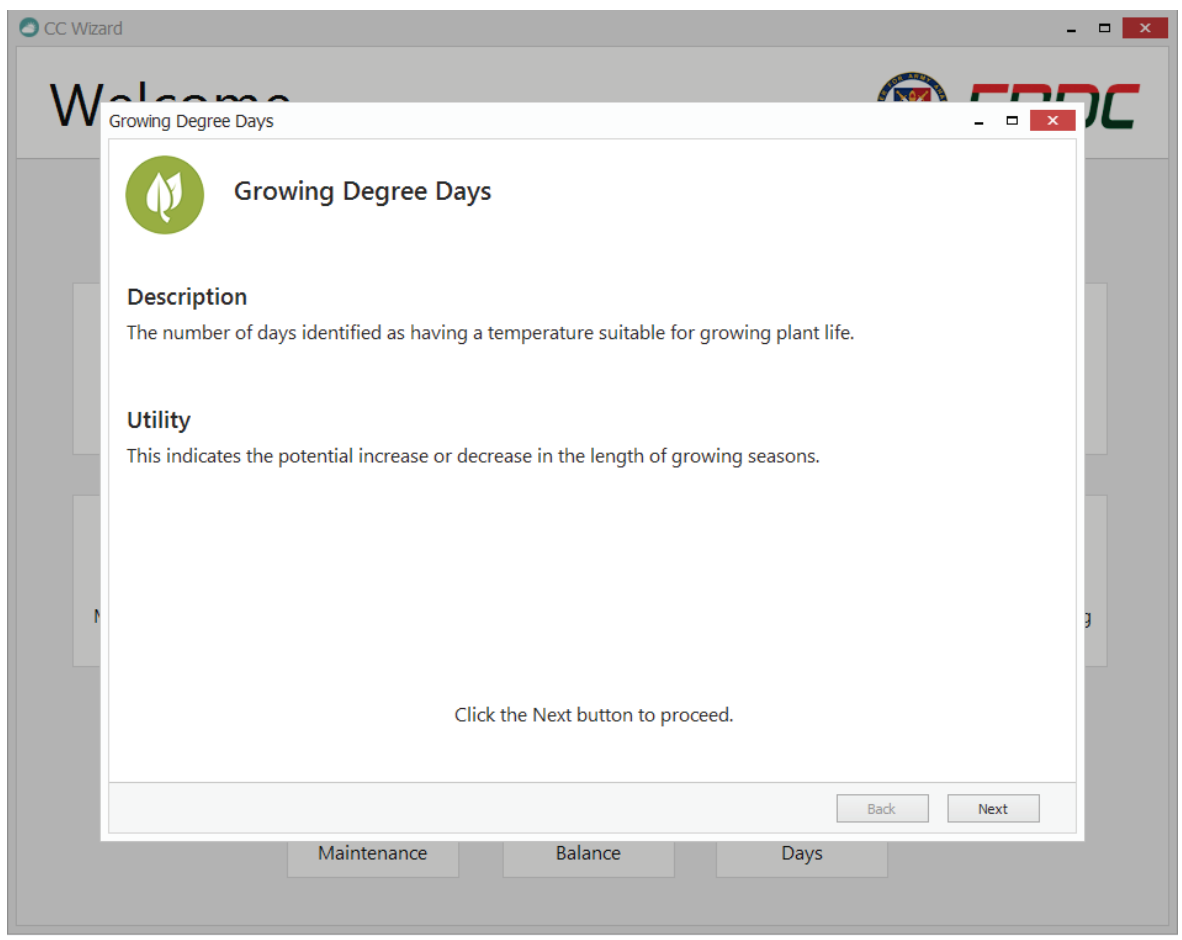

The second screen within the model (Figure 4) allows the end user to view the datasets in graphical or tabular mode. Users can choose the desired view type from the View drop down combo box. Options within this box 
are Graphs and Tabular. Graphs displays the data as standard line graphs while Tabular displays the data in a table layout within an MS Excel ${ }^{\circledR}$ spreadsheet.

Figure 4. Growing Degree Days Model second screen.

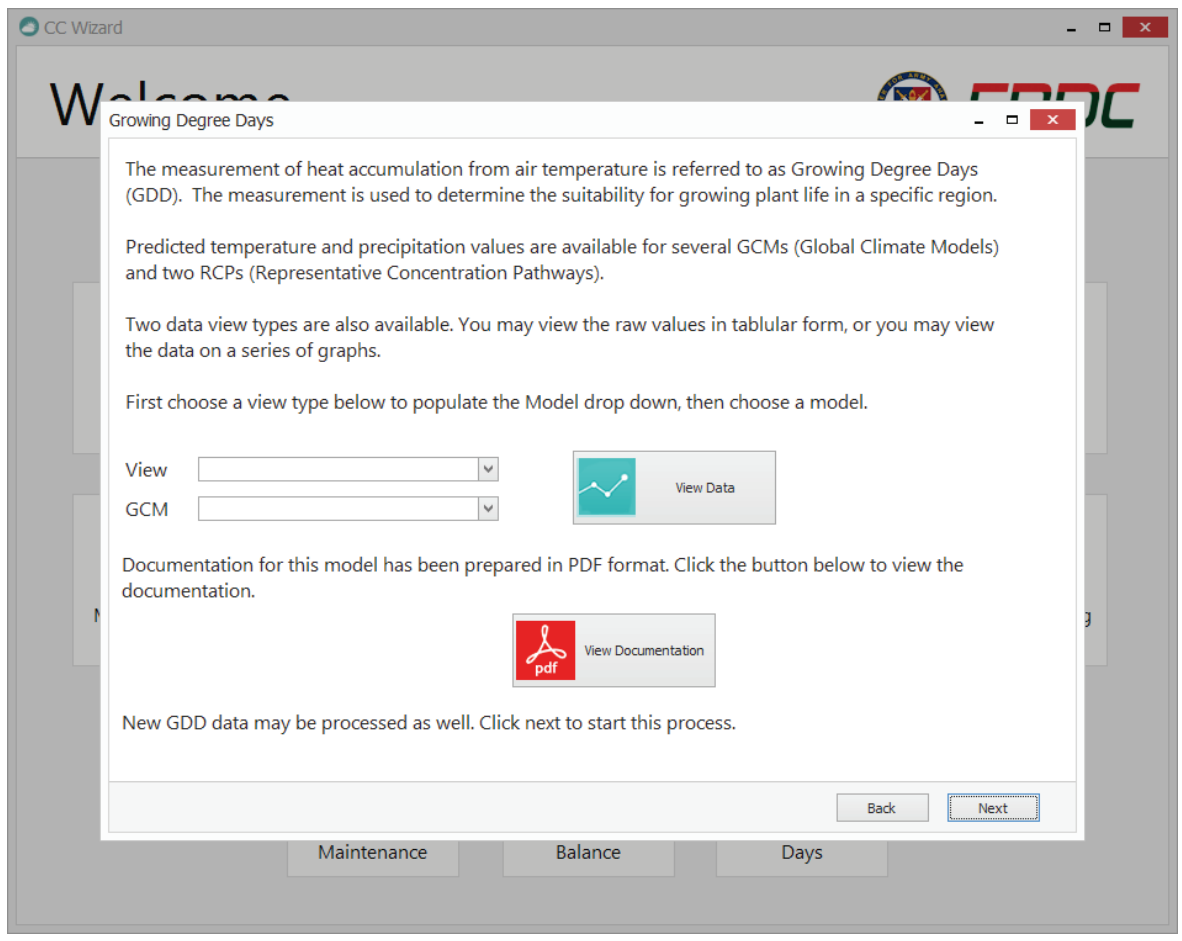

Next, choose a General Circulation Model (GCM) and Representative Concentration Pathway (RCP) type from the drop down combo box to filter only data related to that GCM/RCP. At the time of this publication, there are ten GCMs within the dataset for this model. RCP 2.6, 4.5, and 8.5 were chosen to represent lower bound, middle, and upper bounds for each GCM. Each GCM contains these RCPs, with the exception of CNRM-CM-5 and GFDL-CM3.

Once both of the choices are made, click the View Data button to launch the chart viewer window (Figure 5). 
Figure 5. Results in the chart viewer window.

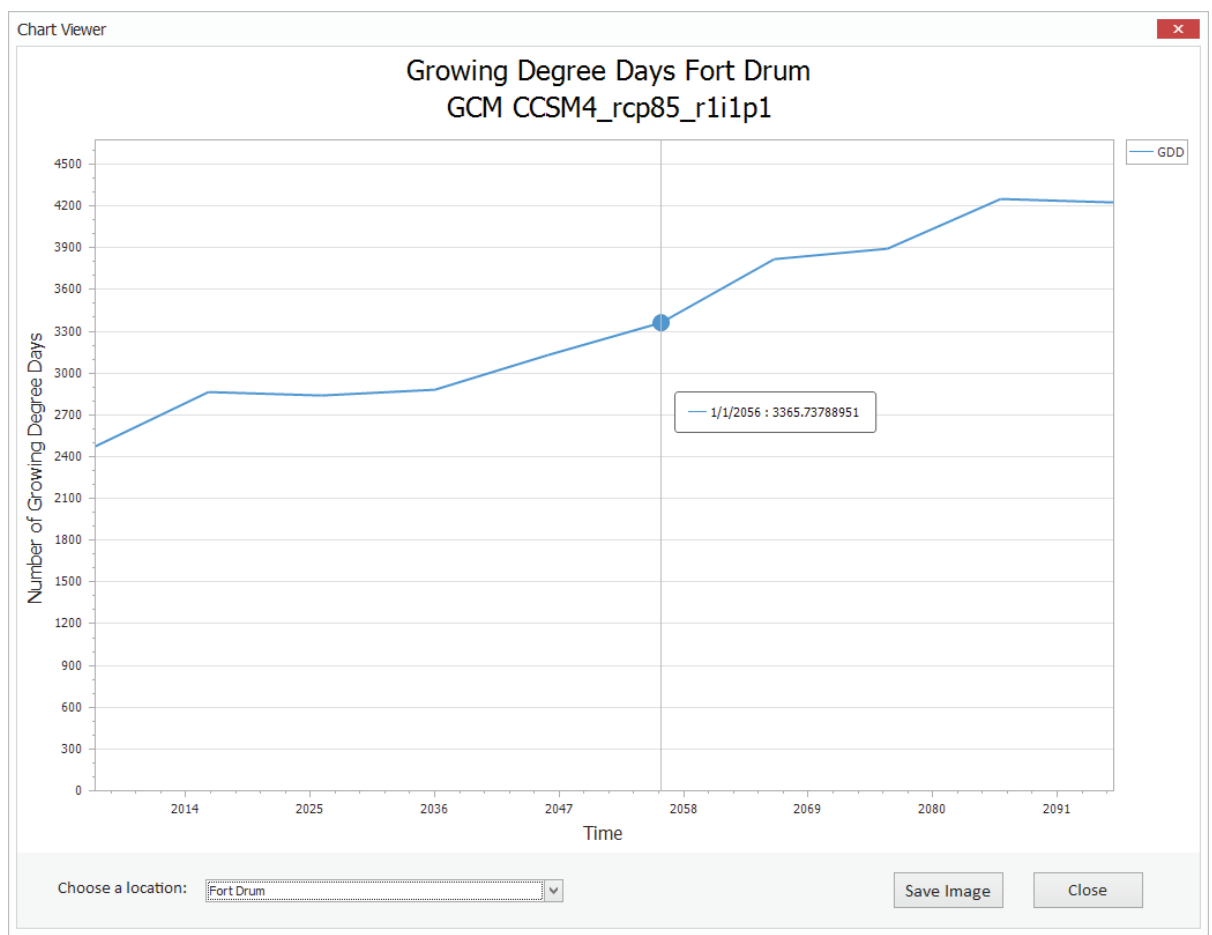

The average number of growing degree days for epochs ending in 2100 is plotted as a line graph with the number of days charted on the $\mathrm{Y}$-axis, and 10-year epochs are charted on the $\mathrm{X}$-axis. The user can change the charted values by choosing a different geographical location from the drop down combo box near the bottom left of the window (Figure 5). Upon selecting a location, the data will automatically filter to include only those values found within the chosen area.

Charts can be saved to the user's computer by clicking the Save Image button near the bottom right of the window (Figure 5). The resulting file is saved to a location of the user's choosing in the universal Joint Photographic Experts Group (JPEG) image file format. 


\section{Building New Data}

Building new datasets is not possible within the Wizard interface but can be accomplished within the VM by running a Python Script from the Python IDLE development environment. The following instructions should be followed carefully to produce new data from this model.

The Python IDLE development environment is pre-installed inside the VM, and may be launched automatically from the Wizard application or accessed from the Windows Start menu (Figure 6 and Figure 7).

Figure 6. Launch Python IDLE from the third model screen within the Wizard.

Growing Degree Days
New growing degree day data can be generated using Python script. This script also produces data
for several other models.
This process includes multiple steps that require user interaction. Unfortunately, the process is not
automated. Instructions on how to proceed are available by clicking the documentation button below.


Figure 7. Python IDLE development environment.

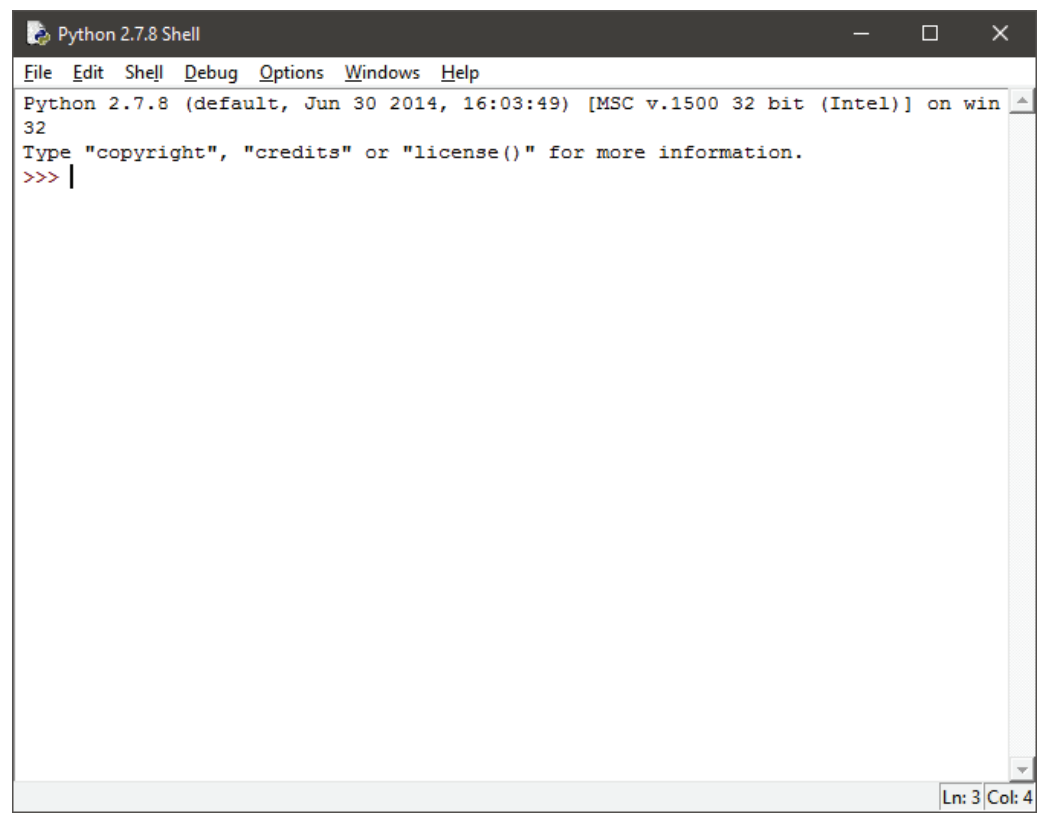

After opening IDLE, open the Python script by selecting File->open and browse to the file $C: \backslash$ Models $\backslash$ SharedData $\backslash$ Model $\backslash$ heat-fire risk days climate projections.py. Once the file is loaded, please ensure line 19 points to a text file that contains a list of GCMs to process. This file has been pre-made, so no adjustments to it should be necessary, unless new GCMs are to be processed. The file location is $\mathrm{C}: \backslash$ Mode $1 \mathrm{~s} \backslash$ Data-2 $\backslash \mathrm{GCM}$ Mode 1 Runs . txt. Use a text editor such as Microsoft Notepad to make modifications to this file. Also note that daily climate data from the Temperature and Precipitation Model must be processed prior to running this Growing Degree Days Model. Refer to lines 16-18 for the file paths. If new climate data is to be processed, the files that are output from the Temperature and Precipitation Model must be located in the same prior directory, or lines 16-18 must be modified to match the location of the output files. Refer to the user's guide for that model for more information about its output files.

Output from this model is in the form of Comma Separated Values (CSV) files, one for each GCM/RCP combination. Please note that this process can be rather lengthy, depending on the number of GCMs that are being processed. It's not unusual for the script to run for several hours.

After running the Python script, another post processing script must be run. Locate the EXE file in the model folder within VM. 
(C: $\backslash$ Models $\backslash$ Shared-Data $\backslash$ DataFixer.exe). Set the input and output paths by clicking the Change buttons. Ensure that the output folder that's entered exists before starting the process. Finally, click Fix It to process the data (Figure 8 ).

Figure 8. Data Fixer tool.

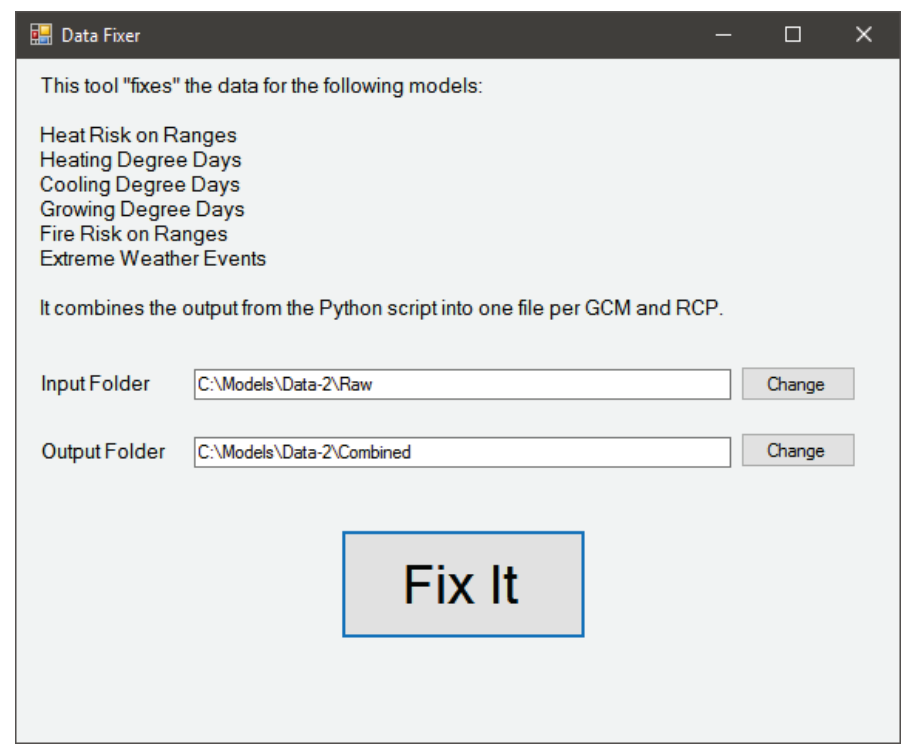

Post processing the data is fairly quick. It should not take more than a couple of minutes to complete. After this step, the data is ready to be viewed within the Wizard application. The post processing application source code is located at $\mathrm{C}: \backslash$ Model $\backslash \mathrm{s} \backslash \mathrm{VS}$

Projects $\backslash$ DataFixerHeatFire. 


\section{Known Issues and Limitations}

Building new data with this model can be a very lengthy process.

Depending on the number of GCM's being processed, it is not unusual for the Python script to take several hours complete, even on very powerful, modern computers. 


\section{Additional Help}

Additional questions or concerns should be directed to the Program Manager of the Integrated Climate Assessment for Army Enterprise Planning program.

Paul M. Loechl

ERDC-CERL

Paul.M.Loechl@usace.army.mil

217-373-5892

Marty Garton

ERDC-ITL

Byron.m.garton@usace.army.mil

601-634-2888 


\section{Reference}

Garton, B. M. 2019. Analytical Model Software Integration Methods. ERDC/ITL SR-194. Vicksburg, MS: Information Technology Laboratory - U.S. Engineer Research and Development Center. 


\section{Appendix A: Acronyms and Abbreviations}

Term

CSV

DoD

ERDC

ERDC-CERL

ERDC-ITL

\section{Definition}

Comma Separated Values

Department of Defense

Engineer Research and Development Center

Engineer Research and Development Center, Construction Engineering Research Laboratory

Engineer Research and Development Center, Information Technology Laboratory

Global Circulation Model

Growing Degree Days

JPEG

MVA

NSN

$\mathrm{OMB}$

PM

$\mathrm{RCP}$

SAR

SSB

$\mathrm{VM}$
Joint Photographic Experts Group

Military Value Analysis

National Supply Number

Office of Management and Budget

Program Manager

Representative Concentration Pathway

Same As Report

Scientific Software Branch

Virtual Machine 


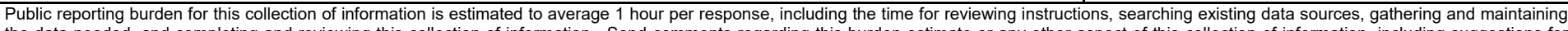

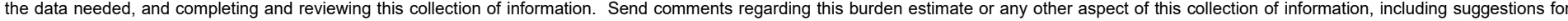

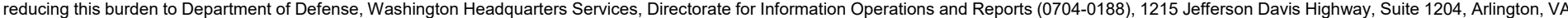

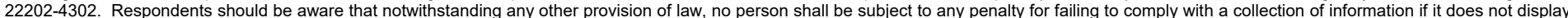
a currently valid OMB control number. PLEASE DO NOT RETURN YOUR FORM TO THE ABOVE ADDRESS.
1. REPORT DATE (DD-MM-YYYY) July 2019

4. TITLE AND SUBTITLE

Growing Degree Days Model User's Guide
3. DATES COVERED (From - To)

5a. CONTRACT NUMBER

5b. GRANT NUMBER

5c. PROGRAM ELEMENT NUMBER

5d. PROJECT NUMBER

402188

Byron M. Garton

5e. TASK NUMBER

5f. WORK UNIT NUMBER

8. PERFORMING ORGANIZATION REPORT NUMBER

ERDC/ITL SR-19-8

Information Technology Laboratory

U.S. Army Engineer Research and Development Center

3909 Halls Ferry Road

Vicksburg, MS 39180

9. SPONSORING / MONITORING AGENCY NAME(S) AND ADDRESS(ES)

10. SPONSOR/MONITOR'S ACRONYM(S)

Headquarters, U.S. Army Corps of Engineers

Washington, DC 20314-1000

11. SPONSOR/MONITOR'S REPORT NUMBER(S)

\section{DISTRIBUTION / AVAILABILITY STATEMENT}

Approved for public release; distribution is unlimited

\section{SUPPLEMENTARY NOTES}

\section{ABSTRACT}

Maintaining and increasing the capacity to perform maneuver training exercises on Department of Defense (DoD) lands is essential to future force readiness and effectiveness. The risk of reduction of vegetation growth on ranges as a potential result of climate change is one factor affecting the availability of training areas. Assessing the impact of future climate change is an essential part of ensuring future availability of maneuver ranges.

This document describes the process of executing the Growing Degree Days Model, as it exists at the time of this writing, within the common computational environment established under the software integration effort of the Integrated Climate Assessment for Army Enterprise Planning work package.

\section{SUBJECT TERMS}

Long-range weather forecasting

Military bases

Vegetation management

\section{SECURITY CLASSIFICATION OF:}

\section{a. REPORT}

Unclassified

\section{b. ABSTRACT}

Unclassified

\section{c. THIS PAGE}

Unclassified
17. LIMITATION OF ABSTRACT
Plants--Effect of global warming on

Climatic changes--Risk assessment
18. NUMBER OF PAGES

21 19a. NAME OF RESPONSIBLE PERSON

19b. TELEPHONE NUMBER (include area code) 